\title{
Primary Brain Tumors Associated with Cerebral Aneurysm: Report of Three Cases
}

\author{
Serebral Anevrizma ile Birlikte Olan Primer Beyin Tümörleri: \\ $\ddot{U}$ ç Olgu Sunumu
}

Hikmet TURAN SUSLU, Mustafa BOZBUGA

Dr. Lutfi Kirdar Kartal Education and Research Hospital, Department of Neurosurgery, Istanbul, Turkey

Correspondence address: Hikmet TURAN SUSLU / E-mail: hikmets1972@yahoo.com

\begin{abstract}
The primary brain tumors associated with cerebral aneurysms are rare in neurosurgical practice. The present article constitutes an evaluation of the management of coexistent primary brain tumor and cerebral aneurysm. A retrospective study of three cases of primary brain tumor with cerebral aneurysm was performed. We evaluated the complications and clinic outcomes by assessing the clinical and imaging findings. Case 1 presented with a subarachnoid hemorrhage from an aneurysm of the anterior communicating artery, with an incidental left frontal oligodendroglioma. Case 2 presented with chronic headache due to left frontal convexity meningioma, with proximal internal carotid artery aneurysm which was found incidentally during preoperative magnetic resonance angiography. Case 3 was admitted to our hospital complaining of headache, memory disturbance, and weakness in her left lower extremity. Magnetic resonance imaging revealed right frontal lymphoma and an unruptured aneurysm at the left middle cerebral artery. Preoperative magnetic resonance imaging revealed right frontal lymphoma and unruptured left middle cerebral artery. The frequency of primary brain tumor and cerebral aneurysm coexistence is increasing due to improvements in high-resolution imaging. In these complicated cases, the management will differ according to each pathology present, and this is an important problem for a neurosurgeon.
\end{abstract}

KEYWORDS: Aneurysm, Lymphoma, Meningioma, Primary brain tumor, Oligodendroglioma, Brain tumors

öz

Primer beyin tümörleri ve serebral anevrizma birlikteliği nöroşirürji pratiğinde nadirdir. Bu makale primer beyin tümörü ve serebral anevrizma birlikteliğinin idaresinin değerlendirilmesini içermektedir. Primer beyin tümörü ve serebral anevrizmalı üç hasta retrospektif olarak incelendi. Klinik ve görüntüleme bulgularının değerlendirilmesi ile komplikasyonlar ve klinik sonuçlar değerlendirildi. Olgu 1 insidental sol frontal oligodendrogliomu olup anterior komünikan arter anevrizmasına bağlı subaraknoid kanama ile presente oldu. Olgu 2, sol frontal konveksite meningiomu nedeniyle oluşan başağrısı ile presente oldu ve preoperatif magnetik rezonans angiografi ile tespit edilen insidental proksimal karotid arter anevrizması tespit edildi. Olgu 3 başağrısı, hafıza değişikliği, sol alt ekstremite zayıflığı ile başvurdu. Magnetik rezonans görüntülemede sağ frontal lenfoma ve rüptüre olmamış sol orta serebral arter anevrizması saptandı. Primer beyin tümörü ve serebral anevrizma birlikteliğinin sıklığı yüksek rezolüsyonlu görüntüleme tekniklerindeki ilerlemeler nedeniyle artmıştır. Bu komplike vakalarda, olguların değerlendirilmesi her bir patolojiye göre yapılır ve bu nöroşirürjiyen için önemli bir problemdir.

ANAHTAR SÖZCÜKLER: Anevrizma, Lenfoma, Meningiom, Primer beyin tümörü, Oligodendrogliom, Beyin tümörü

\section{INTRODUCTION}

Based on autopsy and angiography studies, the incidence of intracranial aneurysms are reported to range from 1-7\% (20). Using brain magnetic resonance (MR) imaging, it is estimated that the prevalence of asymptomatic cerebral aneurysm is $1.8 \%$ and the prevalence of asymptomatic primary brain tumor is $1.7 \%$ (33). The incidence of the coexistence of primary brain tumor and cerebral aneurysm is approximately $1 \%(5,12,22,32)$. This incidence is not higher than that of incidental aneurysms or asymptomatic primary brain tumors but the prevalence of incidentally discovered primary brain tumor and cerebral aneurysm has increased by improvement of high-resolution imaging techniques. The true incidence may be higher as cerebral four vessel angiography, MR angiography, and 3D computed tomography (CT) angiography are not routinely performed for brain tumors.

A primary brain tumor associated with cerebral aneurysm is uncommon in practice. Despite the presence of basic principles for the clinical management of these pathologies, management is dependent on many factors such as the pathogenesis, the presenting pathology, the surgeons skills and preferences. In this paper we discuss the clinical management, etiology and treatment modalities based on literature in 3 cases of primary brain tumor and cerebral aneurysm co-existence. 


\section{CASE REPORT}

Case 1: A 36-year-old man was admitted to our clinic with sudden onset of headache over the last few days. There was slight psychic slowness on neurological examination. Cranial CT showed subarachnoid hemorrhage $(\mathrm{SAH})$ and a left frontal mass. The cranial MRI demonstrated massive SAH and a mass in the left frontal region (Figure1). The left frontal mass did not cause edema or shift. Spontaneous SAH may develop in primary brain tumors. The differential of whether the SAH was caused by the mass or the cerebral aneurysm had to be made and cerebral angiography was therefore performed. The four vessel cerebral angiography revealed an anterior communicating artery (AComA) (4.2x $2.9 \mathrm{~mm}$ ) aneurysm. The clinical symptoms were attributed to the AComA aneurysm and a clipping procedure was performed. During the craniotomy, the frontal mass appeared resectable and therefore both pathologies were treated in the same session. Five days after admission, a left frontotemporal craniotomy was carried out. First, clipping of the AComA aneurysm via a left pterional approach was performed. Second, the left frontal mass was resected with same craniotomy at the same season. The histological examination of frontal mass revealed oligodendroglioma (WHO grade II). The patient has remained well, with no recurrence noted by MRI examination of the frontal mass for 22 months.

Case 2: A 41-year-old female was admitted to our clinic with chronic headache. Cranial MRI showed a mass of the left frontal region with homogeneous enhancement after intravenous contrast and an internal carotid artery aneurysm (Figure 2). Due to the presence of an aneurysm on MRI, the decision to perform an angiography was made. The fourvessel angiography showed an aneurysm of the cavernous segment of the internal carotid artery (Figure 3). The patient consented to tumor removal only. The asymptomatic intracavernous aneurysm was left untouched. The operation was performed a left frontal craniotomy. The dural origin of neoplasm was coagulated and the mass was removed. The histological examination showed a fibroblastic meningioma (WHO grade I). The patient tolerated the procedure well. At two years follow-up the patient was in excellent health.

Case 3: A 67-year-old female was admitted to our hospital complaining headache, memory disturbance, and weakness in her left lower extremity. MRI showed a mass in the right frontal region, peripheral edema and midline shift, and a left middle cerebral artery (MCA) aneurysm (Figure 4). MR angiography and cerebral angiography demonstrated an aneurysm at the junction of the left MCA. As the clinical findings were due to the right frontal mass, the MCA aneurysm was unruptured and the lesions were at a different region, a decision to first perform a tumor resection was made. The frontal mass was removed with a right frontal craniotomy. Histological examination of the mass found diffuse B-cell Non-Hodgkin lymphoma (NHL). Postoperative recovery was uneventful. The prognosis was unfavorable and the patient was scheduled for chemotherapy and radiation therapy. The

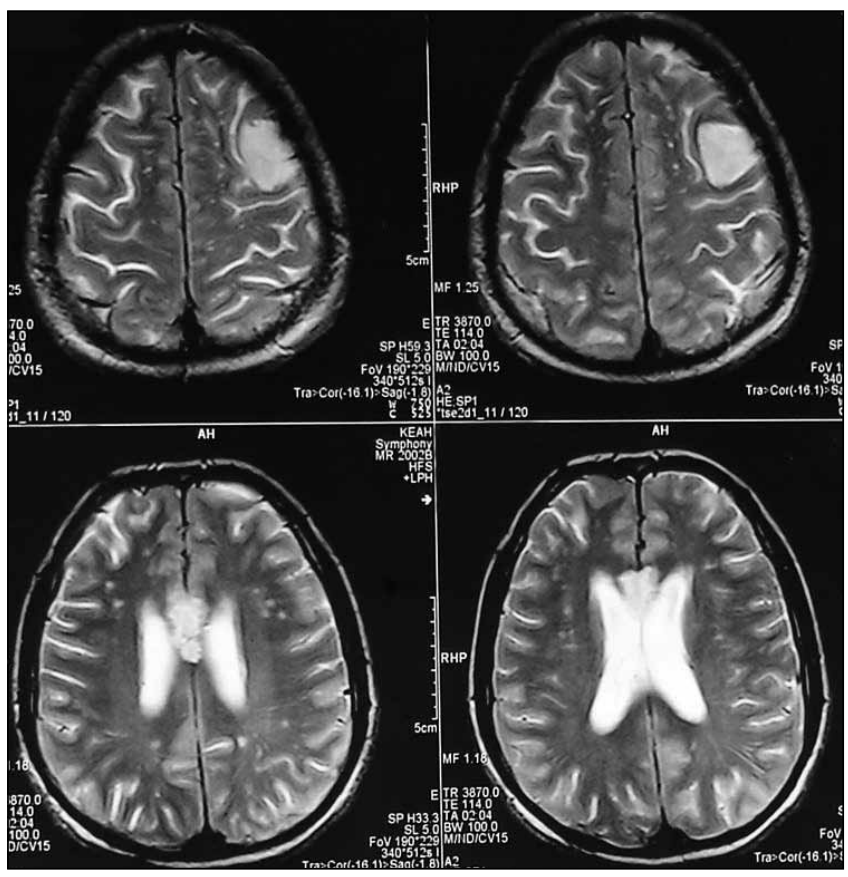

Figure 1: A 36-year-old man was admitted to our clinic with sudden onset of headache over the next few days. Axial MRI with left frontal mass and subacute interhemispheric hemorrhage. There was no evidence of surrounding edema and hydrocephalus. Intraarterial digital cerebral angiography of the left carotid artery in the anteroposterior view shows an aneurysm arising on AComA.

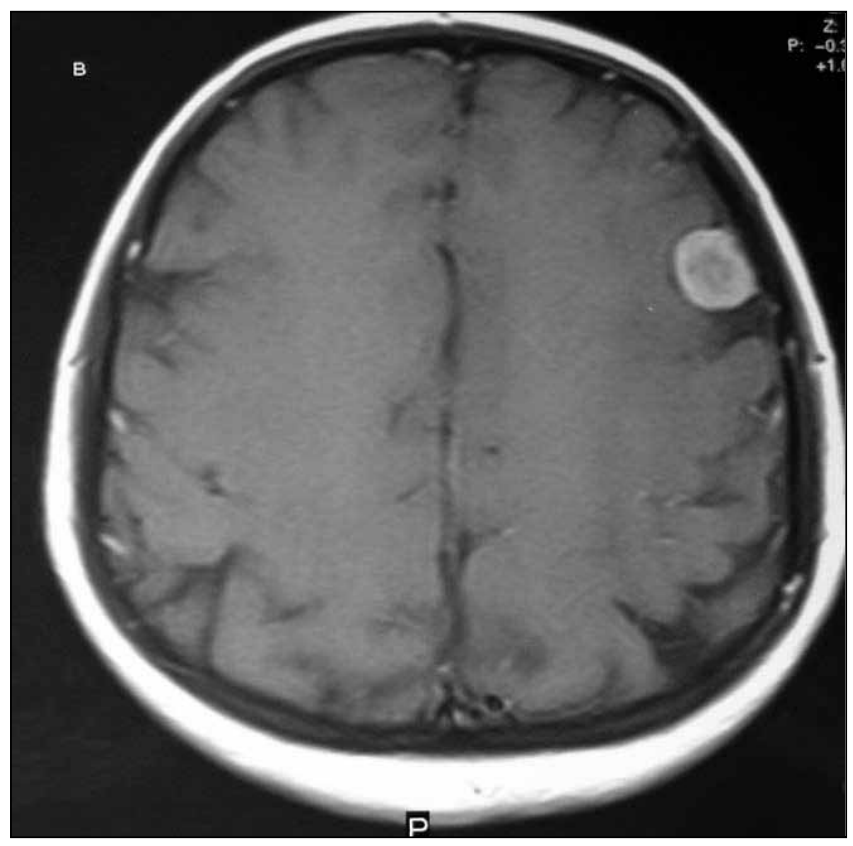

Figure 2: A 47-year-old female was admitted to our clinic with chronic headache. Cranial MRI showed a mass of left frontal region with homogeneous enhancement after intravenous contrast. 


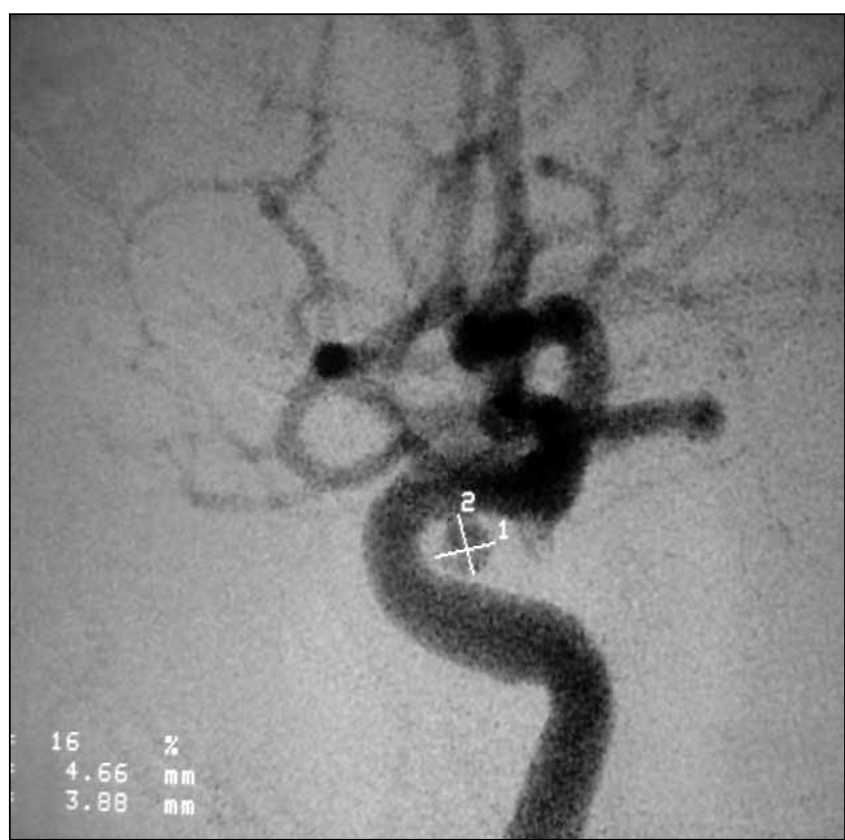

Figure 3: Cerebral angiography of case 2 demonstrated a 4.6 x $3.8 \mathrm{~mm}$ right cavernous segment of internal carotid artery aneurysm.

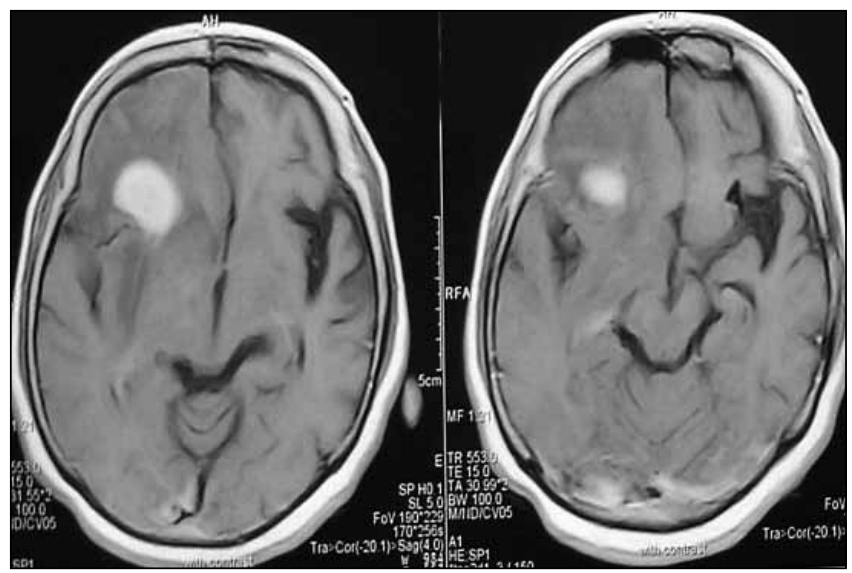

Figure 4: This 67-year-female is presented with headache, memory disturbance, and weakness in her left lower extremity. The MRI revealed a mass arising in the right frontal region with perilesional edema and left MCA aneurysm. The mass was completely removed via a right frontal craniotomy. MCA aneurysm was not clipped. The patient made a good recovery but died after 6 months.

unruptured aneurysm was left untouched. Radiation therapy (41 Gy of 60Co) and adjuvant chemotherapy were started for the frontal mass. Long term survival was not expected due to the pathology of the resected tumor, and a second operation was therefore not performed in order to prevent complications related to aneurysm surgery. The patient died within 6 months.

\section{DISCUSSION}

Cerebral aneurysm has been associated with a wide variety of tumor types, including meningioma (29.3-44\%), glioma (27.5-38\%), pituitary adenoma (11-20.6\%), lymphoma, craniopharyngioma, chordoma, epidermoid tumor, dermoid tumor, and choroid plexus adenoma (10, 16, 22, 23, 25, 30). Initial symptoms were caused by the tumor (54-78\%) or by the rupture of the aneurysm $(17-45 \%)(16,22,24)$. Symptoms from both tumor and aneurysm were recorded in $6 \%$ of cases $(16,22)$.

The association of brain tumors with cerebral aneurysms raises the question of whether a causal relationship exists. The relationship of tumor of aneurysm in all cases remains speculative. Several hypotheses have been proposed to explain the possible association of tumor with aneurysm. An increase in the directional blood flow due to a higher blood supply to a meningioma or malignant glioma may induce secondary changes in the arterial wall and thus facilitate the formation of aneurysms $(8,22)$. The role of growth hormone in promoting vascular disease is directly as a predisposing factor for aneurysm formation $(21,22)$. However, there are authors who state that hormones have no effect on the formation of aneurysms. $(12,21)$. Intracranial tumor surgery may also cause traumatic aneurysms $(9,29)$. In aneurysms that are within or adjacent to a brain tumor, the tumor invasion of the aneurysm wall point toward a causal relationship between the growth of the tumor and the development of the aneurysm $(3,17,23)$. Development of cerebral aneurysm by tumor invasion is linked to the histology of tumor (2). Vessel wall invasion by tumor cells may occur in glial tumors, lymphomas, and pituitary tumors $(2,15,17,23)$ but vessel wall invasion by tumor cells is not reported in meningioma (28). The inflammatory process in epidermoid and dermoid tumors leads to aneurysm formation (1). Dysgenetic factors may underlie the development of multiple aneurysms in meningiomas and various congenital tumors (22). There are also completely coincidental existing tumors and aneurysms in which none of these etiological factors can be found. In these cases the unruptured aneurysm was an incidental finding at cerebral angiography, MR angiography, and 3D computed tomography angiography performed for tumor documentation.

Coexistent primary central nervous system lymphoma (PCNSL) and cerebral aneurysm without phakomatoses or radiation therapy is very rare but has been described. We have identified 3 reported cases of coexistent PCNSL and cerebral aneurysm in the English literature $(23,25,30)$ (Table I). Shigemori et al. reported lymphoma and meningioma with unruptured MCA aneurysm (25). First, the resection of left frontal meningioma and clipping of the MCA aneurysm was performed. After two months, diffuse Burkitt-type lymphoma was found at the same site. Lymphoma may have resulted from the irritating effect of the first tumor in this case (25) but the association of the cerebral aneurysm was considered purely coincidental. Roitberg et al. reported a patient with 
Table I: Cases of Intracranial Aneurysms with PCNSL in the Literature (without Systemic Involvement, and Phakomatosis)

\begin{tabular}{|c|c|c|c|c|c|c|c|c|}
\hline Ref & $\begin{array}{l}\text { Age } \\
\text { /male }\end{array}$ & LL & $\mathbf{L T}$ & $\begin{array}{l}\text { Additional } \\
\text { tumor }\end{array}$ & Aneurysm & VIT & Treatment & Follow-up \\
\hline 25 & $49 / \mathrm{M}$ & $\begin{array}{c}\text { left } \\
\text { frontal }\end{array}$ & Burkitt & $\begin{array}{l}\text { left frontal } \\
\text { meningioma }\end{array}$ & $\begin{array}{l}\text { left M1 } \\
\text { portion }\end{array}$ & $(-)$ & $\begin{array}{l}\text { resection of meningioma and } \\
\text { lymphoma, } \\
\text { clipping of aneurysm }\end{array}$ & 6 months \\
\hline 23 & $65 / M$ & $\begin{array}{c}\text { left } \\
\text { frontal }\end{array}$ & B-cell & $(-)$ & $\begin{array}{l}\text { AComA, left } \\
\text { PComA }\end{array}$ & $(+)$ & $\begin{array}{c}\text { stereotactic biopsy of tumor, } \\
\text { embolization and clipping of } \\
\text { aneurysm }\end{array}$ & 3 months \\
\hline 30 & $56 / \mathrm{M}$ & $\begin{array}{l}\text { choroid } \\
\text { plexus }\end{array}$ & T-cell & $(-)$ & $\begin{array}{c}\text { AchoA, } \\
\text { PComA, } \\
\text { bilateral ICA }\end{array}$ & $(-)$ & $\begin{array}{l}\text { CSF cytology for mass, } \\
\text { endovascular coiling of } \\
\text { aneurysms }\end{array}$ & 19 months \\
\hline $\begin{array}{l}\text { Our } \\
\text { case }\end{array}$ & $67 / F$ & $\begin{array}{l}\text { right } \\
\text { frontal }\end{array}$ & B-cell & $(-)$ & left MCA & $(-)$ & $\begin{array}{l}\text { resection of tumor, no } \\
\text { treatment of aneurysm }\end{array}$ & 6 months \\
\hline
\end{tabular}

(Ref: reference, LL: Lymphoma location, LT: Lymphoma type, VIT: Vascular invasion with tumor, anterior choroidal artery: AchoA, posterior communicating artery: PComA, internal carotid artery: ICA, middle cerebral artery: MCA, cerebrospinal fluid: CSF)

association of a large B-cell lymphoma with giant AComA and posterior communicating artery (PComA) aneurysms. The AComA aneurysm was treated with Guglielmi detachable coils (23). The PComA aneurysm was clipped. Six months later, a stereotactic biopsy of the lymphoma in striatum and internal capsule plus clipping of the AComA aneurysm was performed . Histopathological examination of the AComA aneurysm wall revealed infiltration of the aneurysm wall by lymphoma. Terasaki et al. reported a patient with primary choroid plexus lymphoma and multiple cerebral aneurysms (30). The patient presented with tumor of the choroid plexus. Cerebral angiography showed multiple aneurysms (anterior choroidal artery, PComA, and bilateral internal carotid arteries). A causal relationship is not clear in the association of PCNSL with cerebral aneurysm. The histopathological findings of PCNSL include densely cellular lesions consisting of atypical lymphoid cells with an angiocentric growth pattern at the margins of the infiltrate and a rich reticulin network dissociating the vascular wall (14). Roitberg et al. reported lymphoma adjacent to an aneurysm in which the wall was weakened, and the aneurysm was growing (23). Our patients had no systemic disease or evidence of immunodeficiency. Right frontal lymphoma association with unruptured left MCA aneurysm was considered purely coincidental. Only the mass was resected since the patient was consulted for the brain tumor, the MCA aneurysm was unruptured and the tumor and aneurysm were in different regions. Long term survival was not expected due to the pathology of the resected tumor, therefore a second operation was not performed in order to prevent complications related to aneurysm surgery.

Coexistent glial tumor (glioblastoma, anaplastic astrocytoma) and cerebral aneurysms are common but associated cranial oligodendroglioma and cerebral aneurysms are rare $(22,18)$. Coexistent gliomas and cerebral aneurysms are generally located in the same region $(3,4)$. In the case that the tumor and aneurysm are in the same region, histopathological examination for infiltration of the aneurysm wall from neoplastic cells has been demonstrated $(3,4,7)$ but a rapid growth of the tumor does not give enough time to produce mechanisms which could lead to the formation of an aneurysm (5). Intracerebral or intracerebellar, intratumoral, subdural, subarachnoid hemorrhage may occur in primary brain tumors (13). Spontaneous cranial hemorrhage has been reported in high grade glial tumors and generally an intratumoral or intracerebral/intracerebellar hemorrhage occurs in glial tumors (13). Spontaneous SAH is not common in high grade glial tumors. Aneurysms in patients with glial masses must therefore be investigated if spontaneous $\mathrm{SAH}$ occurs. Our case presented with $\mathrm{SAH}$ and the mass diagnosed incidentally. The decision was made to perform a cerebral angiography to determine if the bleeding was due to a ruptured aneurysm or from the frontal mass. The angiography revealed a AComA aneurysm. The AComA aneurysm was clipped first. Secondly, the frontal mass was resected by the same craniotomy at same session. The association of the AComA aneurysm with frontal mass was considered purely coincidental in our case.

The most frequent intracranial tumor associated with aneurysm is the meningioma (29.3\%) (8). Multiple aneurysms seem to be higher in meningiomas (26). Meningioma and aneurysms are reported to be observed on the same side in $80 \%$ of patients (24). The artery most commonly involved by aneurysms with convexity meningiomas is the MCA. There is a predominance of ICA and ACoA aneurysms in anterior fossa meningiomas $(8,22,24)$. A local circulatory change due to the presence of the tumor may be responsible of the aneurysmal growth as in the association ICA-ACA aneurysms and basal meningiomas (22). Aneurysm may locate on the artery feeding the meningioma $(19,27)$ In our case, the frontal mass was removed and the asymptomatic intracavernous aneurysm was left untouched. The frontal meningioma association with intracavernous fusiform aneurysm was considered purely coincidental. 
Treatment decisions have been made according to the symptoms produced by the lesion, the locations of tumor and aneurysm, and the nature of the neoplasm (benign or malignant) (16). Surgical treatment was undertaken in $72 \%$ of all cases (16). The treatment options of an aneurysm with primary brain tumor include conservative management (if unruptured), surgical clipping of the aneurysm and excision of the tumor either simultaneously or sequentially, or endovascular coiling of the aneurysm followed by surgical excision of the tumor $(3,6,11,22,24)$. Clipping for ruptured cerebral aneurysm and resection of the brain tumor is the best treatment option. The aneurysm and the tumor have been discovered at the same time. The tumor was so near to the aneurysm that the same craniotomy could be employed for the approach to both lesions $(16,25)$. The lesion producing the presenting symptoms should be treated first when a single approach to both is unfeasible (33).

When the treatment and natural course of unruptured aneurysms (without primary brain tumor) is investigated, around $30 \%$ of patients do not require surgical treatment (31). In patients where surgical treatment is not performed, the rate of rupture is around $3.42 \% /$ year (31). In patients who have surgery, the mortality rate is $3.1 \%$ (31). When these figures are considered, decisions regarding exclusion of an incidental aneurysms should be balanced against the risks of the procedure (16). The incidental aneurysm may be managed conservatively in patients with co-incidental tumor and aneurysm if it is not in the field of surgery for the tumor (22). The presence of an incidental aneurysm close to or embedded within the tumor makes the surgical excision of the tumor hazardous (11). Resection of the tumor can be performed following endovascular Guglielmi detachable coil embolization of the aneurysms (11). The reason to coil the aneurysm is to avoid the risk of intraoperative rupture and to enable total tumor removal (11). Our opinion is that it is unnecessary to operate incidental aneurysm with a different craniotomy in the patient with high grade glial tumor or PCNSL. In patients with very little long term survival, it is better to protect the patient from surgical complications and not perform surgery on the aneurysm.

The prognosis was linked mainly to the nature of the tumor with unruptured aneurysms (benign, malignant), and to the evolution of SAH in patients with ruptured aneurysms (16). Death occurred mainly due to progressive evolution of the malignant tumor $(46 \%)$ or fatal aneurysmal bleeding (23\%) (20). The localization and the pathological nature of the tumor are the most important prognostic factors (28). Association of both lesions did not worsen the outcome (16).

The brain tumor association of cerebral aneurysm in our cases was considered purely coincidental. There was no direct contact between the tumors and the aneurysm, and no increased blood supply from the cerebral artery to the tumors was found by preoperative angiography. In our three cases the tumors were resected, and ruptured aneurysm clipping was managed conservatively for the unruptured aneurysms localized differently from the tumor.

\section{CONCLUSION}

The prevalence of incidentally discovered brain tumor and cerebral aneurysm have been increased by the improvement of high-resolution imaging techniques. The use of additional advanced imaging, such as 3D CT angiography, MR angiography, and cerebral angiography, for screening patients is likely necessary. Adequate knowledge of this association is a precondition to plan the correct surgical approach of these cases and avoid life-threatening complications. The tumor pathology is the primary guide for treatment. Treatment of the co-incidental aneurysm depends on whether it has ruptured, its location with respect to the tumor and the surgeons preferences. Based on previously reported cases and those we present, treatment must be made on a case to case basis, with the tumor pathology being the main guide.

\section{REFERENCES}

1. Ahmad I, Tominaga T, Ogawa A, YoshimotoT: Ruptured suprasellar dermoid associated with middle cerebral artery aneurysm: Case report. Surg Neurol 38:341-346, 1992

2. Aichholzer M, Gruber A, Haberler C, Bertalanffy A, Slave I, Czech T: Intracranial hemorrhage from an aneurysm encased in a pilocytic astrocytoma: Case report and review of the literature. Child Nervous Syst 17:173-178, 2001

3. Andrews BT, Raffel C, Rosegay $\mathrm{H}$ : Subarachnoid hemorrhage from a peripheral intracranial aneurysm associated with malignant glioma. Report of a case. Neurosurgery 17:645-649, 1985

4. Barker CS: Peripheral cerebral aneurysm associated with a glioma. Neuroradiology 34: 30-32, 1992

5. Brzezinski J, Kotwica Z, Polis Z: Brain tumors associated with intracranial vascular anomalies. ZBL Neurochir 50:201-202, 1989

6. Cheng WY, Shen CC: Minimally invasive approaches to treat simultaneous occurrence of glioblastoma multiforme and intracranial aneurysm: Case report. Minim Invas Neurosurg 47:181-185, 2004

7. Cowen RL, Siqueria EB, George E: Angiographic demonstration of a glioma involving the wall of the anterior cerebral artery. Radiology 97:577-578, 1970

8. Deflini R, Domenicucci M, Ferrari M: Association of intracranial meningiomas and aneurysms. J Neurosurg Sci 34:51-56, 1990

9. Dunn IF, Woodworth GF, Siddiqui AH, Smith ER, Vates GE, Day AL, Goumnerova LC: Traumatic pericallosal artery aneurysm: A rare complication of transcallosal surgery. Case report. J Neurosurg 106:153-157, 2007

10. Goodman ML, Nelson PB: Association of an epidermoid tumor with an aneurysm of the anterior communicating artery. Neurosurgery 23:392-395, 1988

11. Javadpour $M$, Khan $A D$, Jenkinson $M D$, Foy $P M$, Nahser $H C$ : Cerebral aneurysm associated with an intracranial tumor: Staged endovascular and surgical treatment in two cases. $\mathrm{Br} J$ Neurosurg 18:280-284, 2004

12. Handa J, Matsuda I, Handa H: Association of brain tumor and intracranial aneurysms. Surg Neurol 6:25-29, 1976

13. Iwama T, Ohkuma A, Mıwa Y, Sugımoto S, Itoh T, Takada M, Tanabe Y, Funakoshı T, Sakaı N, Yamada H: Brain tumors manifesting as intracranial hemorrhage. Neurol Med Chir (Tokyo) 32:130-135, 1992 
14. Kalimo $H$, Lehto $M$, Näntö-Salonen $K$, Jalkanen $M$, Risteli L, Risteli J, Narva EV: Characterization of the perivascular reticulin network in a case of primary brain lymphoma. Immunohistochemical demonstration of collagen types I, III, IV and V; laminin; and fibronectin. Acta Neuropathol (Berl) 66:299-305, 1985

15. Kung PC, Lee JC, Bakay L: Vascular invasion by glioma cells in man: An electron microscopic study. J Neurosurg 31:339-345, 1969

16. Licata C, Pasqualin A, Freschini A, Barone G, Da Pian R:Management of associated primary cerebral neoplasms and vascular malformations. Acta Neurochir (Wien) 82:28-38, 1986

17. Mangiardi JR, Aleksic SN, Lifshitz M, Pinto R, Budzilovic GN, Pearson J: Coincidental pituitary adenoma and cerebral aneurysm with pathological findings. Surg Neurol 19:38-41, 1983

18. Mathuriya SN, Khosla VK, Banerjee AK, Kak VK. Bifrontal oligodendroglioma with bilateral symmetrical posterior communicating artery aneurysms. Neurochirurgia (Stuttg) 35:23-25, 1992

19. O'Neill OR, Barnwell SL, Silver DJ: Middle cerebral artery aneurysm associated with meningioma: Case report. Neurosurgery 36: 396-398, 1995

20. Osborn AG: Diagnostic cerebral angiography, vol 3-193, 2nd edn. 1999, Lippincott Philadelphia: Williams\&Wilkins, 1999: 241-274

21. Pant B, Arita K, Kurisu K, Tominaga A, Eguchi K, Uozumi T: Incidence of intracranial aneurysm associated with pituitary adenoma. Neurosurg Rev 20:13-17, 1997

22. Pia HW, Obrador S, Martin JD: Association of brain tumors and arterial intracranial aneurysms. Acta Neurochir 27: 189-204, 1972

23. Roitberg BZ, Cochran EJ, Thornton J, Charbel FT: Giant anterior communicating artery aneurysm infiltrated with a primary cerebral lymphoma: Case report. Neurosurgery 47:458-462, 2000
24. Scamoni C, Dorizzi A, Dario A, Marra A, Pozzi M: Intracraial meningioma associated with cerebral artery aneurysm. J Neurosurg Sci 41:273-281, 1997

25. Shigemori M, Tokunaga T, Miyagi J, Eguchi G, Kuramoto S, Irie $\mathrm{K}$, Morimatsu M: Multiple brain tumors of different cell types an unruptured cerebral aneurysm. Case report. Neurol Med Chir (Tokyo) 31:96-99, 1991

26. Spallone A, Tcherekayev VA: Simultaneous occurrence of aneurysm and multiple meningioma in Klippel-Trenaunay patients: case report. Surg Neurol 45:241-244, 1996

27. Tachikawa T, Adachi J, Nishikawa R, Matsutani M: An anterior ethmoidal artery aneurysm associated with an olfactory meningioma. J Neurosurg 97:1479, 2002

28. Tancioni F, Egitto MG, Tartara F: Aneurysm occuring within a meningioma: Case report. Br J Neurosurg 12:588-591, 1998

29. Taylor PE: Delayed postoperative hemorrhage from intracranial aneurysm after craniotomy for tumor. Neurology 11:225-231, 1961

30. Terasaki M, Abe T, Tajima Y, Fukushima S, Hirohata M, Shigemori M: Primary choroid plexus T-cell lymphoma and multiple aneurysms in the CNS. Leuk Lymphoma 47:1680-1682, 2006

31. Tsukahara T, Murakami N, Sakurai Y, Yonekura M, Takahashi $T$, Inoue T, Yonekawa Y: Treatment of unruptured cerebral aneurysms; a multi-center study at Japanese national hospitals. Acta Neurochir Suppl 94:77-85, 2005

32. Vernooij MV, Ikram MA, Tanghe HL, Vincet AJPE, Hofman A, Krestin GP, Niessen WJ, Breteler MMB, van der Lugt A: Incidental findings on brain MRI in the general population. New Engl J Med 357:1821-1828, 2007

33. Yamada $\mathrm{H}$, Taomoto K: Postoperative subarachnoid hemorrhage from an intracranial aneurysm after craniotomy for astrocytomacase report. Neurol Med Chir (Tokyo) 29:846-849, 1989 